\title{
Penilaian PEDS pada Anak Usia 6-72 bulan
}

Hesti Lestari*, Rini Sekartini**

* Divisi Tumbuh Kembang-Pediatri Sosial Bagian Ilmu Kesehatan Anak Fakultas Kedokteran Universitas Sam Ratulangi Manado

** Divisi Tumbuh Kembang-Pediatri Sosial, Departemen Ilmu Kesehatan Anak Fakultas Kedokteran Universtas Indonesia Jakarta

Latar belakang. Pemantauan tumbuh kembang secara berkala sangat penting untuk mendeteksi secara dini penyimpangan perkembangan anak. Tahap awal penapisan perkembangan dapat melibatkan orangtua dan setelah diketahui anak memerlukan evaluasi lebih lanjut, dilakukan uji tapis yang lebih rinci dan kompleks. Salah satu instrumen uji tapis yang peruntukkan pada orangtua adalah parents evaluation of developmental status (PEDS).

Tujuan Penelitian. Penelitian bertujuan untuk mengetahui penggunaan PEDS sebagai alat uji tapis perkembangan anak dan mengetahui sebaran kekhawatiran orangtua pada aspek perkembangan yang dinilai dalam kuesioner PEDS.

Metode. Penelitian deskriptif potong lintang dilakukan pada 82 anak sehat berusia 6-72 bulan di Yayasan Balita Sehat, Jakarta pada bulan Agustus 2006 sampai dengan September 2006. Pengisian kuesioner uji tapis perkembangan PEDS dilakukan dengan cara wawancara.

Hasil. Dari 82 anak yang diteliti, 16 (19,5\%) anak termasuk dalam langkah A yaitu kelompok risiko tinggi untuk mendapatkan masalah perkembangan dan memerlukan rujukan untuk evaluasi lebih lanjut. Langkah B yaitu 33 (40,2\%) anak termasuk kelompok risiko sedang dan memerlukan skrining, stimulasi dan pemantauan lanjut, kelompok risiko rendah $14(17,1 \%)$ anak termasuk langkah C memerlukan bimbingan tingkah laku dan 19 (23,2\%) anak termasuk langkah E yaitu berisiko rendah dan hanya perlu pemantauan rutin.

Kesimpulan. Kelompok risiko tinggi dan sedang kelainan perkembangan pada penelitian ini lebih tinggi dari penelitian lain. Hal yang mungkin berperan adalah tingginya kekhawatiran orangtua terhadap penyakit dan masalah kesehatan lainnya yang dalam uji tapis PEDS merupakan indikator bermakna adanya gangguan perkembangan (Sari Pediatri 2007; 9(10):7-12).

Kata kunci: deteksi dini, perkembangan anak, PEDS

\footnotetext{
Alamat korespondensi

Dr. Hesti Lestari, SpA.

Divisi Tumbuh Kembang-Pediatri Sosial, Bagian Ilmu Kesehatan Anak FK

Unsrat - RSU Prof. Dr. R. D. Kandou. Jl. Raya Tanawangko, Manado 95115.

Telepon: 0431-821652 fax.: 0431-859091. E-mail: ikarsup@telkom.net
}

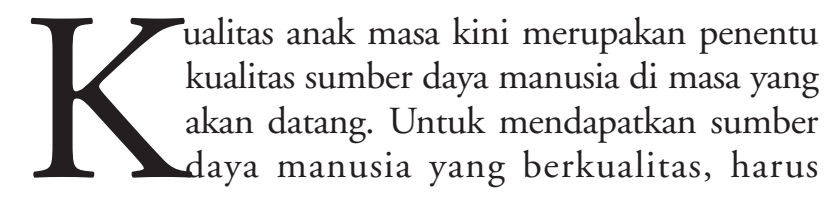

Sari Pediatri, Vol. 9, No. 1, Juni 2007 
dimulai sejak dini dengan melakukan pemantauan tumbuh kembang secara berkala. ${ }^{1-6}$ Saat ini alat penapisan perkembangan anak yang dapat digunakan spesialis anak dan petugas kesehatan lainnya makin berkembang dari tahun ke tahun, sehingga deteksi terhadap adanya penyimpangan perkembangan anak dapat lebih mudah dan dapat dilakukan sedini mungkin. Alat uji tapis yang digunakan harus mempunyai sensitivitas (dapat mendeteksi dengan benar anak yang tidak mempunyai kelainan atau keterlambatan) dan spesifitas (dapat mendeteksi dengan benar anak yang mempunyai kelainan atau keterlambatan) paling sedikit 70\%-80\%. ${ }^{7}$ Namun, pelaksanaan uji tapis umumnya membutuhkan waktu cukup lama yaitu berkisar 30-45 menit, sehingga hanya sebagian dokter yang melakukan pemeriksaan uji tapis perkembangan anak secara rutin di tempat prakteknya.-10

Untuk mengatasi masalah lamanya waktu pelaksanaan uji tapis, American Academy of Pediatrics (AAP) ${ }^{11}$ merekomendasikan penapisan perkembangan dilakukan dalam dua tahap. Pertama, dapat dilakukan oleh orang tua yang bertujuan untuk identifikasi sebanyak mungkin anak yang dicurigai mempunyai hambatan dalam perkembangan. Tahap selanjutnya adalah penentuan anak yang memerlukan evaluasi lebih lanjut dan dilakukan uji tapis untuk deteksi lebih rinci dan sifatnya lebih kompleks.

Salah satu kuesioner yang ditujukan pada orangtua dikembangkan oleh Glascoe ${ }^{12,13}$ yaitu metode parents evaluation of developmental status (PEDS). Kuesioner ini dapat diselesaikan dalam 5 menit, mempunyai sensitivitas $74 \%-79 \%$ dan spesifisitas $70 \%-80 \% .{ }^{14}$ Dengan PEDS seluruh aspek perkembangan anak seperti aspek kognitif, bahasa ekspresif dan reseptif, motorik kasar dan halus, perilaku, emosi sosial, kemandirian, dan sekolah dapat diketahui. Setelah dilakukan PEDS, dokter kemudian melakukan langkah selanjutnya sesuai hasil interpretasi. ${ }^{15-18}$

Penggunaan PEDS sebagai alat uji tapis perkembangan anak yang menggunakan kuesioner pada orangtua belum dilaporkan dalam kepustakaan di Indonesia. Tujuan penelitian untuk mengetahui penggunaan PEDS sebagai alat uji tapis perkembangan anak

\section{Metode}

Penelitian menggunakan metode survei, deskriptif, dengan desain potong lintang. Subjek penelitian adalah anak sehat berusia 6-72 bulan. Penelitian dilakukan pada bulan Agustus 2006 sampai dengan September 2006 di Yayasan Balita Sehat, Jakarta. Kriteria penolakan jika anak menderita kelainan bawaan, dijumpai gangguan penglihatan dan atau pendengaran atau orangtua menolak pemeriksaan yang akan dilakukan pada anak.

Pencatatan data dasar meliputi usia dan jenis kelamin anak serta pendapatan keluarga, pendidikan ibu, status perkawinan ibu dan jumlah anak. Pemeriksaan fisik, pengukuran tinggi dan berat badan anak dilakukan untuk penentuan status gizi. Selanjutnya pengisian kuesioner uji tapis perkembangan PEDS dengan cara wawancara oleh peneliti.

Perangkat uji tapis yang digunakan dalam penelitian ini adalah PEDS bahasa Indonesia ${ }^{15}$ (Lampiran 1) terdiri dari 10 pertanyaan yang meliputi seluruh aspek perkembangan anak yaitu aspek kognitif, bahasa ekspresif maupun reseptif, motorik kasar dan halus, perilaku, emosi sosial, kemandirian, sekolah dan penyakit/ kelainan lain. Ditanyakan adakah kekhawatiran orangtua tentang aspek perkembangan anak. Orangtua dapat menjawab 'ya', 'tidak' atau 'sedikit' khawatir. Jika orangtua menjawab 'ya' atau 'sedikit' orangtua diminta untuk memberikan jenis atau contoh keterlambatan atau gangguan yang menjadi kekhawatiran orangtua tersebut. Peneliti kemudian mengisi lembar penilaian sesuai umur anak. Pada jawaban pertanyaan nomor 1 , kemudian ditentukan termasuk kategori aspek perkembangan yang mana, sedangkan untuk pertanyaan nomor 2 hingga 10 diberi tanda pada kotak sesuai dengan umur anak.

Peneliti kemudian menghitung jumlah kotak berwarna dan tidak berwarna. Jika jumlah kotak berwarna bernilai 2 atau lebih, dikelompokkan dalam langkah A. Jika kotak berwarna berjumlah 1, dikelompokkan dalam langkah B. Jika jumlah kotak tidak berwarna 1 atau lebih dan kotak berwarna bernilai 0 dikelompokkan dalam langkah C. Jika didapatkan nilai 0 untuk kotak berwarna maupun tidak berwarna, tetapi orangtua mempunyai masalah komunikasi yang mungkin disebabkan masalah bahasa, kurang akrab dengan anak atau masalah mental orangtua maka dikelompokkan dalam langkah D. Jika didapatkan nilai 0 untuk kotak berwarna maupun tidak berwarna dan orangtua dapat berkomunikasi dengan baik dikelompokkan dalam langkah E.

Responden yang ikut serta dalam penelitian ini diberi jaminan kerahasiaan atas data wawancara yang diberikan maupun data pertumbuhan dan perkembangan anaknya. Responden berhak menolak ikut serta penelitian ataupun membatalkan persetujuan ikut serta dalam penelitian. 


\section{Hasil}

Dari 84 responden yang setuju ikut penelitian, 1 anak dikeluarkan dari penelitian karena menderita penyakit jantung bawaan dan 1 orang anak karena diantar ayah yang tidak mengetahui secara pasti data anaknya. Dengan demikian data yang diolah berasal dari 82 anak.

Karakteristik subjek dan responden penelitian diperlihatkan pada Tabel 1. Dari 82 anak, didapatkan rerata usia adalah 47,34 (SD 16,242) bulan. Berdasarkan status gizi, didapatkan $46(56,1 \%)$ subjek tergolong gizi kurang. Sebagian besar responden 61 $(74,4 \%)$ memiliki tingkat pendidikan rendah dan 53 $(64,6 \%)$ responden memiliki pendapatan rendah. Status perkawinan terbanyak adalah menikah 77 (93,9\%), dan yang memiliki 2-3 anak 46 (56,1\%).

Hasil pemeriksaan PEDS tertera pada Gambar 1, langkah B merupakan kelompok terbanyak yaitu 33 $(40,2 \%)$ anak, berarti mereka memiliki risiko sedang untuk mendapatkan masalah perkembangan dan memerlukan skrining, stimulasi dan pemantauan lanjut. Tidak terdapat anak yang termasuk dalam kelompok langkah D.

Rekapitulasi pertanyaan PEDS tertera pada Gambar 2. Dari 10 pertanyaan PEDS, 41 (50\%) responden memiliki kekuatiran dalam pertanyaan nomor 6 dan 10 yaitu mengenai perilaku anak dan adanya penyakit atau kelainan lain pada anak.

\section{Diskusi}

Prevalensi gangguan perkembangan anak seperti keterlambatan motorik, berbahasa, perilaku, autis, dan hiperaktif dalam beberapa tahun terakhir ini

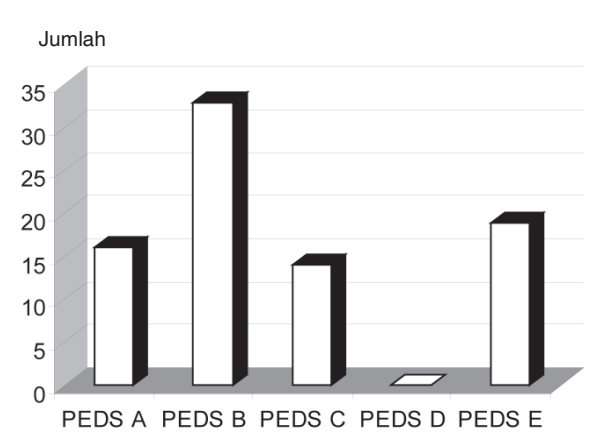

Gambar 1. Sebaran hasil pemeriksaan PEDS semakin meningkat. Angka kejadian gangguan atau penyimpangan perkembangan pada anak bervariasi 10\%-17\% didapatkan dengan menggunakan berbagai uji tapis perkembangan. ${ }^{8,10,11}$ Febrianti $^{20}$ mendapatkan $14,4 \%$ anak usia 3-24 bulan diduga mengalami keterlambatan perkembangan dengan uji tapis Kuesioner Pra Skrining Perkembangan (KPSP), sedangkan Harahap ${ }^{21}$ mendapatkan hasil 22,8\% anak usia di bawah dua tahun memiliki keterlambatan perkembangan dengan uji tapis Denver II dan $11,41 \%$ anak memiliki keterlambatan perkembangan

Tabel 1. Karakteristik subjek dan responden penelitian

\begin{tabular}{|c|c|c|}
\hline Karakteristik subjek penelitian & Jumlah & Persentase \\
\hline \multicolumn{3}{|l|}{ Umur (bulan) } \\
\hline Balita $(6-60)$ & 60 & 73,2 \\
\hline Anak pra sekolah $(>60-72)$ & 22 & 26,8 \\
\hline \multicolumn{3}{|l|}{ Jenis kelamin } \\
\hline Laki-laki & 27 & 32,9 \\
\hline Perempuan & 55 & 67,1 \\
\hline \multicolumn{3}{|l|}{ Status gizi $(\mathrm{BB} / \mathrm{TB})^{\wedge}$} \\
\hline Gizi kurang & 46 & 56,1 \\
\hline Gizi cukup & 35 & 42,7 \\
\hline Gizi lebih & 1 & 1,2 \\
\hline \multicolumn{3}{|l|}{ Status pendidikan ibu ${ }^{\#}$} \\
\hline Rendah & 61 & 74,4 \\
\hline Sedang & 20 & 24,4 \\
\hline Tinggi & 1 & 1,2 \\
\hline \multicolumn{3}{|l|}{ Tingkat pendapatan keluarga ${ }^{+}$} \\
\hline Rendah & 53 & 64,6 \\
\hline Menengah rendah & 29 & 35,4 \\
\hline Menengah tinggi & 0 & 0 \\
\hline Tinggi & 0 & 0 \\
\hline \multicolumn{3}{|l|}{ Status perkawinan } \\
\hline Kawin & 77 & 93,9 \\
\hline Janda & 5 & 6,1 \\
\hline \multicolumn{3}{|l|}{ Jumlah anak (orang) } \\
\hline 1 & 28 & 34,1 \\
\hline $2-3$ & 46 & 56,1 \\
\hline$>3$ & 8 & 9,8 \\
\hline \multicolumn{3}{|c|}{$\begin{array}{l}\text { A Status gizi kurang } 70-90 \% \text {; Gizi cukup } 90-110 \% \text {; Gizi lebih } \\
110-120 \% \text { dari klasifikasi Waterlow }{ }^{19} \\
\text { \#Pendidikan ibu rendah jika tidak tamat / tamat SD atau SMP/ } \\
\text { sederajat, Tidak tamat SMU atau sederajat; Tingkat pendidikan } \\
\text { sedang jika tamat SMU/sederajat atau tidak tamat akademi/ } \\
\text { sederajat; Tingkat pendidikan tinggi jika tamat akademi/ perguruan } \\
\text { tinggi atau sederajat } \\
\text { +Pendapatan keluarga rendah jika pendapatan per kapita/bulan }< \\
\text { Rp. 643.000-; Menengah bawah Rp. } 643.000,- \text { sampai Rp } \\
\text { 2.536.000,-; Menengah atas Rp. } 2.536 .000,- \text { sampai Rp. } \\
\text { 7.842.000,-; Tinggi > Rp. } 7.842 .000,-\end{array}$} \\
\hline
\end{tabular}


atau developmental quotient (DQ) $<81$ dengan menggunakan pemeriksaan Griffiths. Ermawati ${ }^{22}$ dalam penelitiannya mengenai prevalensi keterlambatan perkembangan pada anak sehat 4-18 bulan yang lahir cukup bulan dengan menggunakan uji tapis Denver II mendapatkan angka prevalensi sebesar $12,8 \%$. Susanah ${ }^{23}$ dalam penelitiannya pada anak balita di daerah kumuh Bandung mendapatkan $28,5 \%$ anak mengalami keterlambatan perkembangan dengan pemeriksaan Denver II. Angka kejadian gangguan perilaku pada anak cukup banyak, yaitu pada umur kurang dari 4 tahun sekitar 13\% sedangkan pada umur $4-16$ tahun sekitar $27 \%$. Deteksi dini gangguan perilaku seperti depresi dan perilaku antisosial pada masa balita dan usia sekolah penting dilakukan karena berpengaruh besar pada kegagalan sekolah, kriminalitas, kekerasan dan bunuh diri. $^{24}$

Glascoe seperti dikutip oleh Dhamayanti ${ }^{16}$ mengidentifikasi tingkat risiko untuk mendapat masalah perkembangan dan tingkah laku anak. Diperoleh hasil bahwa anak yang mempunyai risiko tinggi mendapat kelainan dan memerlukan rujukan untuk evaluasi lebih lanjut (sesuai dengan langkah A) $11 \%$, anak dengan risiko sedang untuk mendapatkan kelainan dan memerlukan skrining, stimulasi dan pemantauan lanjut (sesuai dengan langkah B) $26 \%$, anak dengan risiko rendah untuk mendapat kelainan dan hanya memerlukan bimbingan tingkah laku (sesuai langkah C) 20\%, sementara $43 \%$ anak berisiko rendah dan hanya perlu pemantauan rutin (sesuai langkah E). Dalam penelitian ini didapatkan subjek dengan kecurigaan masalah atau keterlambatan perkembangan (langkah A) $16(19,5 \%)$, langkah B $33(40,2 \%)$, langkah C $14(17,1 \%)$, langkah E 19 (23,2\%). Tidak terdapat subjek yang termasuk dalam langkah D. Bila dibandingkan dengan data yang diperoleh Glascoe tersebut, tampak hasil penelitian ini lebih banyak pada langkah A dan B serta lebih sedikit pada langkah C dan E. Subjek dikelompokkan dalam langkah A pada lembar interpretasi PEDS apabila terdapat 2 atau lebih kekhawatiran yang bermakna terhadap kemungkinan adanya gangguan perkembangan. Jika hanya terdapat 1 kelompok kekhawatiran yang bermakna terhadap kemungkinan adanya gangguan perkembangan maka dikelompokkan dalam langkah B. ${ }^{16}$ Tingginya kelompok langkah A dan B pada penelitian ini dapat disebabkan karena masih tingginya masalah kesehatan di tempat penelitian yang menjadi sumber kekuatiran orangtua.

Dari Gambar 2 tampak kekhawatiran orangtua mengenai perilaku anak, 41 (50\%) responden menjawab 'ya' untuk pertanyaan nomor 6 mengenai perilaku anak. Hal ini menunjukkan perhatian orangtua bukan hanya tertuju pada pertumbuhan fisik anak saja, melainkan juga pada perkembangan mental anak. Dalam penelitian ini tidak ada subjek termasuk dalam langkah D. Subjek dikelompokkan dalam langkah D pada lembar interpretasi PEDS apabila tidak didapatkan kekhawatiran yang bermakna maupun yang tidak bermakna pada pertanyaan PEDS, tetapi orangtua mempunyai kesulitan dalam komunikasi yang mungkin disebabkan oleh hambatan bahasa, kurang akrab dengan anak (orang lain yang mengasuh anak) atau adanya masalah mental pada orangtua. ${ }^{15}$ Tidak terdapatnya langkah D dalam penelitian ini menunjukkan tidak adanya kesulitan komunikasi antara responden dan peneliti karena tidak ada perbedaan bahasa yang digunakan saat wawancara dan seluruh responden mengasuh anaknya sendiri. Jumlah subjek yang termasuk dalam langkah E 19 (23,2\%) anak. Subjek dikelompokkan dalam langkah E pada lembar interpretasi PEDS apabila tidak didapatkan kekhawatiran yang bermakna maupun yang tidak bermakna pada pertanyaan PEDS dan orangtua dapat berkomunikasi dengan baik. Dalam hal ini, walaupun tidak terdapat kekhawatiran responden terhadap perkembangan anaknya, tetap dibutuhkan pemantauan rutin setiap 6 bulan karena sekitar $5 \%$ dari anak-anak ini masih bisa mempunyai masalah atau keterlambatan perkembangan. ${ }^{16}$

Dalam penelitian ini, pengisian kuesioner PEDS dilakukan dengan metode wawancara oleh peneliti.

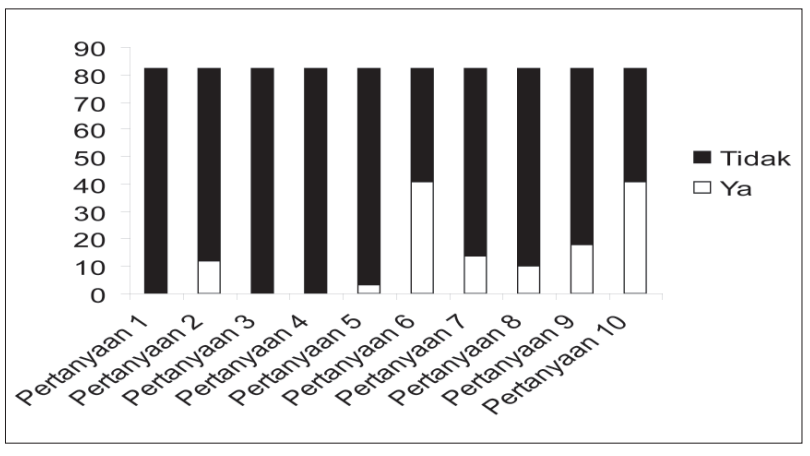

Gambar 2. Distribusi kekuatiran responden sesuai pertanyaan PEDS 
Metode ini dipilih karena sebagian besar responden berasal dari kelompok pendidikan rendah. Dengan metode wawancara perbedaan persepsi responden terhadap pertanyaan pada kuesioner PEDS dapat diminimalkan dengan cara menghindari kesalahpahaman responden terhadap pertanyaan dalam kuesioner tersebut. Peneliti berusaha sedapat mungkin tidak mempengaruhi jawaban responden terhadap pertanyaan kuesioner PEDS yang ditanyakan peneliti. Akan tetapi, pada pelaksanaan wawancara, terdapat juga responden yang tidak mengerti dan bertanya maksud kalimat dalam kuesioner, sehingga peneliti akan memberikan contoh-contoh gangguan perkembangan yang dimaksud.

Penelitian ini memiliki keterbatasan yaitu sebaran kelompok usia dan jenis kelamin subjek yang diteliti tidak dalam proporsi yang sama karena keterbatasan jumlah subjek sesuai kelompok usia dan jenis kelamin yang ada pada tempat penelitian. Selain itu, karena keterbatasan waktu tidak dilakukan pemantauan lanjutan sehingga tidak diketahui bagaimana perkembangan subjek selanjutnya.

Untuk waktu yang akan datang perlu dilakukan penelitian lanjutan sesuai hasil langkah PEDS. Untuk uji tapis perkembangan dapat dilakukan dengan berbagai perangkat antara lain dengan Denver II. ${ }^{5}$ Untuk uji tapis gangguan perilaku anak dapat dilakukan dengan Pediatric Symptom Checklist (PSC). ${ }^{24}$

Sebagai kesimpulan, penggunaan PEDS sebagai alat uji tapis perkembangan pada penelitian ini mendapatkan kelompok risiko tinggi dan sedang kelainan perkembangan yang cukup tinggi. Hal yang mungkin berperan adalah tingginya kekuatiran orangtua terhadap penyakit dan masalah kesehatan lainnya yang merupakan indikator bermakna adanya gangguan perkembangan.

\section{Daftar Pustaka}

1. Soetjiningsih. Upaya peningkatan kualitas tumbuh kembang anak. Dalam: Narendra MB, Sularyo TS, Soetjiningsih, Suyitno H, Ranuh IGNG, penyunting. Buku ajar tumbuh kembang anak dan remaja. Edisi pertama. Jakarta: Sagung Seto; 2002.h.126-35.

2. Needleman RD. Growth and development. Dalam: Berhman RE, Kliegman RM, Jenson HB, penyunting. Nelson textbook of pediatrics. Edisi ke-17. Philadelphia:
WB Saunders; 2004.h.23-57.

3. Soedjatmiko. Deteksi dini gangguan tumbuh kembang balita. Prosiding Simposium Temu Ilmiah Akbar. 2002.

4. Narendra MB. Penilaian pertumbuhan dan perkembangan anak. Dalam: Narendra MB, Sularyo TS, Soetjiningsih, Suyitno H, Ranuh IGNG, penyunting. Buku ajar tumbuh kembang anak dan remaja. Edisi pertama. Jakarta: Sagung Seto; 2002.h.95-111.

5. Sekartini R. Skrining pertumbuhan dan perkembangan anak. Dalam: Pulungan AB, Hendarto A, Hegar B, Oswari $\mathrm{H}$, penyunting. Nutrition, growth-development. Jakarta: IDAI cabang DKI Jakarta, 2006.h.79-92.

6. Departemen Kesehatan RI. Pedoman pelaksanaan stimulasi, deteksi dan intervensi dini tumbuh kembang anak ditingkat pelayanan kesehatan dasar. Jakarta, Departemen Kesehatan RI; 2006.h.48-64.

7. Soetjiningsih. Skrining perkembangan dalam upaya deteksi dini dan meningkatkan kualitas hidup anak. Disampaikan pada Simposium dan pelatihan deteksi dini dan intervensi penyimpangan tumbuh kembang anak. Malang, 13-14 Mei 2006.

8. Blackman JA. Developmental screening: infants, toddlers, and preschoolers. Dalam: Levine MD, Carey WB, Crocker AC, penyunting. Developmental-behavioral pediatrics. Edisi ke-3. Philadelphia: WB Saunders; 1999.h.669-95.

9. Beers N. Developmental screening in the office setting. Diunduh dari http://www.aap.org/compeds/. Diakses pada tanggal 28 Juli 2006

10. Schuster M. Developmental screening. Diunduh dari http://www.rand.org/publications. Diakses pada tanggal 29 Juli 2006

11. American Academy of Pediatrics. Committee on children with disabilities. Developmental surveillance and screening of infants and young children. Pediatrics 2001; 108:192-6.

12. Glascoe FP. Developmental screening. Dalam: Parker S, Zuckerman B, Augustyn M, penyunting. Developmental and behavioral pediatrics. Edisi ke-2. Philadelphia: Lippincott William and Wilkins; 2005.h.41-50.

13. Glascoe FP, Dworkin PH. The role of parents in the detection of developmental and behavioral problems. Pediatrics 1995; 95:829-36.

14. Glascoe FP. Parents concern about children's development: prescreening techniques or screening test? Pediatrics 1995; 99:522-8.

15. Glascoe FP. Developmental/behavior screening: how to do it efficiently and cost effectively and why. Diunduh dari http://www.aap.org/compeds/. Diakses pada tanggal 2 Agustus 2006. 
16. Dhamayanti M. Pemantauan perkembangan anak: penggunaan parents evaluation of developmental status (PEDS) di tempat praktek. Disampaikan pada Simposium dan pelatihan deteksi dini dan intervensi penyimpangan tumbuh kembang anak. Malang, 13-14 Mei 2006.

17. Glascoe FP. Developmental screening. Dalam: Wolraich ML, penyunting. Disorders of developmental learning. Edisi ke-2. St. Louis: Mosby; 1996.h.89-128.

18. Glascoe FP. Developmental/behavior screening: how to do it efficiently and cost effectively and why. Diunduh dari http://www.aap.org/compeds/. Diakses pada tanggal 28 Juli 2006.

19. Sjarif DR. Pediatric nutritional care. Dalam: Pulungan AB, Hendarto A, Hegar B, Oswari H, penyunting. Nutrition, growth-development. Naskah lengkap Continuing Profesional Development IDAI Jaya. Jakarta: IDAI cabang DKI Jakarta; 2006.h.3.

20. Febrianti E. Penilaian kuesioner pra skrining perkembangan (KPSP) dan ages and stages questionnaires (ASQ) untuk deteksi dini keterlambatan perkembangan pada anak bawah dua tahun. Tesis. Jakarta: Program Pendidikan Dokter Spesialis Bagian Ilmu Kesehatan Anak FKUI, 2006.
21. Harahap REG. Perbandingan uji tapis bayley infant neurodevelopmental screener (BINS) dengan uji tapis denver II untuk deteksi dini keterlambatan perkembangan bayi usia 3-24 bulan dengan menggunakan baku emas griffiths mental developmental scales. Tesis. Jakarta: Program Pendidikan Dokter Spesialis Bagian Ilmu Kesehatan Anak FKUI, 2006.

22. Ermawati T, Syarif I, Daili S. Perkembangan bayi/anak sehat usia 4-18 bulan yang berkunjung untuk imunisasi di beberapa puskesmas dan poliklinik IKA RSUP Dr M Djamil Padang. Disampaikan pada 12th National Congress of Child Health, Bali, 30 Juni-4 Juli, 2002.

23. Susanah S, Tanuwidjaja S, Rusmil K. Gambaran perkembangan anak balita di daerah kumuh perkotaan Kelurahan Sukapura Kecamatan Kiaracondong Kotamadya Bandung. Disampaikan pada 12th National Congress of Child Health, Bali, 30 Juni-4 Juli, 2002.

24. Soedjatmiko. Skrining gangguan perkembangan perilaku anak dengan pediatric symptom checklist. Dalam: Tridjaja B, Trihono PP, Ifran EB. Pediatrics up date 2005. Jakarta: IDAI cabang Jakarta; 2005.h.53-8. 